\title{
Weed Mix Pollen Antigen IgG Antibody Measurement
}

National Cancer Institute

\section{Source}

National Cancer Institute. Weed Mix Pollen Antigen Ig G Antibody Measurement. NCI

Thesaurus. Code C130107.

A measurement of the weed mix pollen antigen Ig $G$ antibody in a biological specimen. 